\section{A MODERN ORGAN}

$\mathrm{T} T$ has been hitherto chiefly on the Continent of Europe that connoisseurs in the majestic tones of the king of instruments have had to seek for a grand organ. Though London, the mistress of the world for weallh and magnitude, has churches and chapels innumerable, and orgars by hundreds, scarcely one is of sufficient importance or merit to attract the attention of a stranger. Church organs are, as a rule, small, and built without individuality or character of tone, and generally so placed in the building as to effectually mar in acoustical effect any special merit they might otherwise possess. Of the two or three instruments that have any pretensions to magnitude to which the public has acce-s - at the Albert Hall and the Alexandra and Crystal Palaces, no very lasting impression remains upon the audience beyond that on noise and a distressingly harsh volume of sound, utterly devoid of musical depth and grandeur of tone, and quite different from the pleasing reminiscences that dwell upon the memory from hearing some of their more musical Continental rivals at $\mathrm{Haarlem}$, Freiburg, or Lucerne. To successfully construct a large organ is a work of exceeding difficulty, for not only does size greatly complicate the mechanical action, but the proper distribution and apportionment of the wind to each stop, and the harmonious blending of the whole together in the full organ, demands great knowledge and skill upon the part of the builder. It is for these reasons that very few large organs rise beyond mediocrity, or are noted for the beauty of their tone or the perfection of their mechanism. The great advance in the gereral taste for organ music within the last few years has necessitated an improvement in the mechanical construction of the organ, so as to enable the performer rapidly to command the entire resources of the instrument at will, and give him absolute control over the various sound-combinations and tone-colouring of the different stops, according as they are brought on or off by means of the appliances placed at his disposal.

We give a brief description of the very remarkable organ recently erected at Primrose Hill Road, Regent's Park, remarkable alike for its size, being larger than the great Haarlem organ, its beauty, richness, and grandeur of tone, and the completeness of its mechanism. At present this superb instrument is almost entirely unknown to the musical section of the public. The annexed illustration shows that this organ is one of the first magnitude. It possesses what is known as a 32 -feet metal speaking front, with a corresponding weight of tone throughout the pedal organ, and several organs which together constitute the instrument, and give it its place in the scale of magnitude as compared with the more celebrated of the continental instruments. The instrument in question has several novelties not to be found in other organs. It possesses seven distinct organs : pedal, great, choir, swell, solo, echo, and carillon organs, each extending the full compass of 5 octaves (61 notes) with the exception of pedal organ, 30 notes. These various organs are under the control of the performer by means of four manual key-boards, which together comprise sixty-seven speakingregisters, and these are combined together with various acoustical effects by means of thirty-one mechanical movements, making: a grand total of ninety-eight sound-controlling registers, worked by hand and foot. The entire mechanical action necessary to control these registers and accessory movements is carried out by a novel application of atmospheric vacuum pressure. Two distinct systems of main air trunks extend throughout the interior of the organ in connection with the wind arrangements situated in the basement of the building. One of these systems of trunks is for the purpose of conveying the wind at different pressures to the sound boards of the various organs in connection with the musical speech of the several groups of pipes. Thus the wind supplied to the solo organ, swell reeds, and large pedal reeds, is the heaviest pressure empioyed in the instrument for producing the musical intonation of the pipes, namely, 6 inches. The wind pressure to the sound-boards of the great organ and swell flue work is 4 inches, that of the choir organ 2 inches, and the pressure of wind is again reduced in connection with the sound-boards of the echo organ to half an inch, the lightest wind upon which any organ has ever yet been attenipted to be voiced. This question of wind pressure as affecting the voicing and musical intonation of the pipes of an organ is one of great importance, and upon the skilful adjustment to the size. diameter, and materials of which the pipes are constructed, depends the sweetness and quality of the musical tones produced. In the organ under notice the very light pressure of wind adopted affords an example for careful study and examination First, for the mellow sweetness and beauty of: tone produced ; secondly, for the promptness of speech obtained, as rapid as the articulation of a pianoforte string; and thirdly, for the immense volume of sound and power that can be produced from these lighe pressures, the combined effect of the full oryan rivalling almost the artillery of heaven as thunder crash after crash bursts upon the ear. Much of the harsh unmusical tone of modern organs arises from this desire to obtain power at the expense of music by the employment of an overpressure of wind. That age is not requisite to mellow an organ is demonstrated by listening to the diapasons and foundation stops of the Primrose Hill organ, which have all that ripe and fascinating sweetness of tone characteristic of Silbermann's finest instruments. These light pressures of wind consitute a remarikable feature in the construction of so large an organ. The second series of air truaks which permeate the interior of the instrument are in connection with two large vacuum exhaust bellows which, being continually actuated by the steam-engine used for blowing, maintain a constant vacuum pressure throughout the entire system of trunks, so that at any part of the organ an available mechanical power (that of the pressure of the atmosphere $15 \mathrm{lbs}$. to the square inch of surface) is at hand to be employed for the multitude of purposes required in a large instrument. To be obliged to have recourse to the old system of wooden rods, trackers, levers, and squares in endless complications, would have so weighted and impeded the action of the organ as greatly to destroy its musical capabilities. In most of the large organs constructed both at home and abroad, many parts of the mechanism are far from being so perfect as to leave no room for anything further to be desired, and the executant upon the instrument rarely is able to portray as rapidly his musical creations mechanically at his fingerends as those creations in tone-colour flash through his inind. By the introduction of atmospheric vacuum pressure as the "motor" power, there is no complication of mechanical parts; an almost endless syztem of tubes being carried from the key-board registers to the soundboard sliders of the several organs. These tubes are in connection with powerful exhaust bellows and vacuum power-bellows attached to the sliders, so that any required stop is brought on or off instantaneously, how ever distant from the key-board. These tubes may be bent and twisted round comers in any direction, and the parts of the crgan most difficuit of access easily reached. No mechanical force is therefore necessary to be exerted at the keyboards, the mere touch of a key, register, pedal, or finger-button, at once brings its special tube and exhaust arrangement into operation. The wonderful completeness oi this system of vacuum-tube action is beautifully illustrated by means of the echo organ-a complete instrument of 16 feet tone, situated some 100 feet from the key-boards of the great organ-and supported on corisels against an opposite wall at an elevation of some 30 


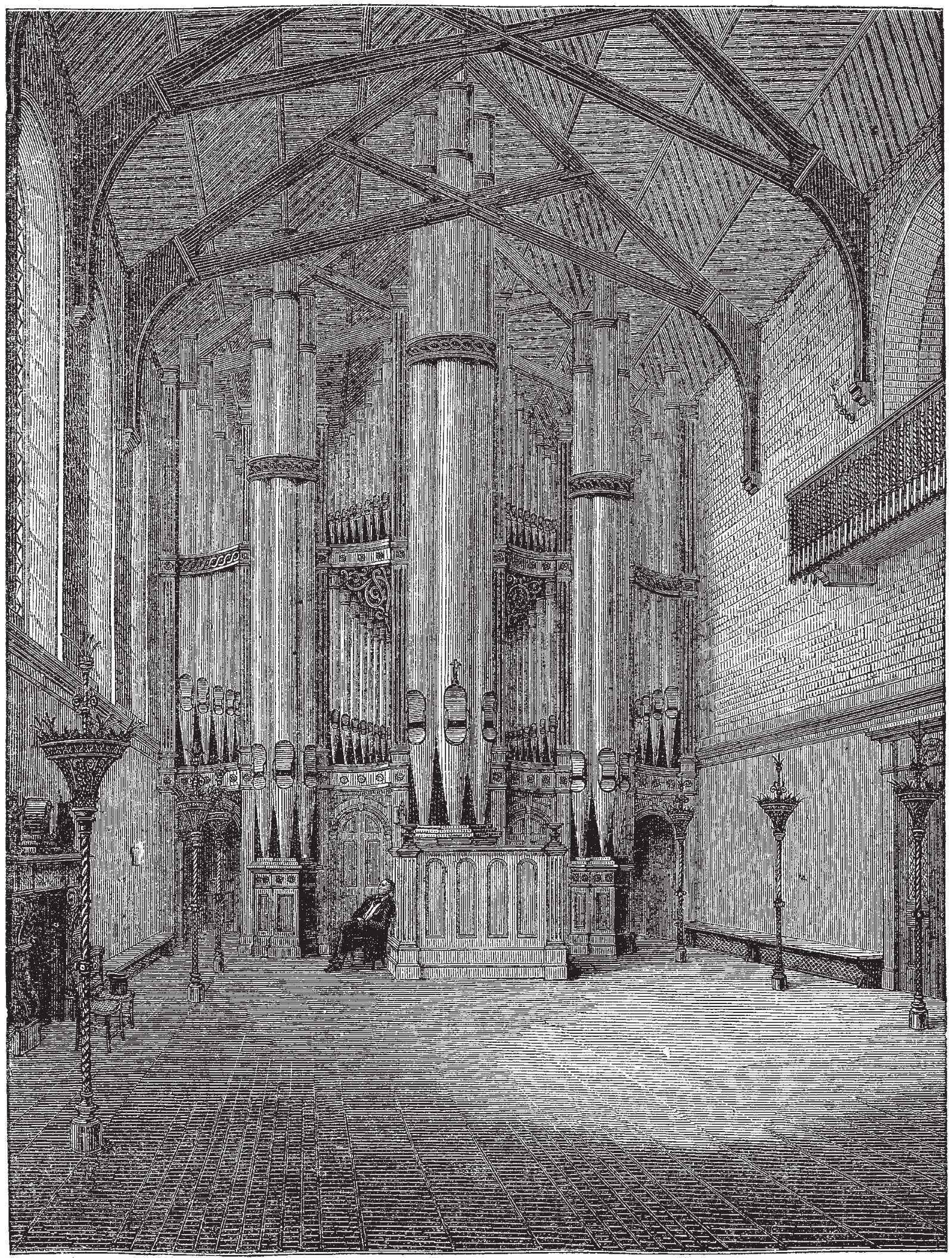

View of "The Great Organ" recently eracted at the Hall, Primrese Hill, London. 
feet from the floor. The action of this organ is electrical, that is, there is no mechanical communication between the performer at the key-board roo feet distant and the organ pallets which admit the wind to the pipes, save a small rope of $6 \mathrm{I}$ insulated copper wires-one wire for each nole of the five octaves. The various stops of this distant organ are likewise controlled without mechanism - a series of vacuum tubes alone extending from the registers at the great organ to the sliders of the echo organ--which are thus brought on or off at the will of the performer by a silent action-at once accurate and instantaneous in its manipulation. The effect of this eche organ, is that of a large organ heard at a great distance. Without the aid of the electric action, and vacuum pressure, such an organ could not have been designed. Mechanical action would never have successfully developed such effects at such an extended distance.

The same vacuum system is also applied to the various pneumatic lever arrangements interposed between the keys at the consol and the wind-valves at the soundboards to relieve the performer from any undue mechanical pressure that might detract from the promptness of repetition and delicacy of touch of the key action, the key boards being thus rendered as light as that of a grand pianoforte. Such results cannot be obtained so efficiently by the employment of compressed air for a pneumatic power action; compressed air will always prove to be more or less sluggish, a "creeping on" and "creeping off" movement being the result, besides a limit to the aguregate of the instantaneous power that is at command.

The pneumatic drawstop action of the St. George's Hall organ, Liverpool, is a fair illustration of the defects of the compressed air system. In the Primrose Hill organ upwards of forty registers can be simultaneously drawn on or shut off as easily and with the same precision as though only a single stop were drawn. The consol or keyboards of this organ, as will be seen by the engraving, are reversed, that is, the performer faces the audience, the organ being behind, and the echo organ opposite him. The lowest keyboard manual is the "great organ;" the next, or second from the bottom, the "choir organ ;" the third in :he series the "swell organ;" and the fourth, or upper row of keys, the "solo organ." By a simple mechanical arrangement this fourth keyboard is also used for the electric "echo organ," and also for the carillon, or "bell" organ, otherwise it would have been necessary to have introduced a fifth set of keys, an arrangement at all times objectionable from the increased complications imposed upon the performer. The touch of the carillon organ on the fourth row of keys is expressive like that of the pianoforte key, and gradations of tone and distance are therefore capable of being expressed upon the bells.

In this organ the French ventil system of shutting off or bringing on the wind to a complete family or group of stops by the depression of a pedal has not been adopted, such a system being found inadequate to effect rapidly the almost endless combinations that such a large instrument has at command, the pneumatic combination foot pedals and finger buttons at the keyboards being introduced as a more convenient form of manipulating the registers.

The wind supply of this gigantic organ is furnished from four large reservoirs in the basement, which again supply seventeen reservoirs in connection with the various scund-boards of the organ; the vertical feeders for producing the wind to these reservoirs, as well as for creating the vacuum pressure, are set in motion by an eleven horsepower steam-engine. The wind supply is so ample, that with the power of the full organ it is impossible to exhaust or create unsteadiness in the wind; few organs are properly constructed in this important respect. An ingenimis automatic lever engine for regulating the motion and the supply of wind from the vertical feeders into the reservoirs according to the demand of the organ, is placed between the steam-engine and the wind reservoirs, so that the regulation of the wind supply is independent of the speed of the engine, which remains constant. This instrument, which occupied three years in its construction, and was opened in January, 1876 , has been erected under the personal supervision of Mr. W. T. Best, of Live rpool, by the eminent organ builders Messrs. Bryceson Brothers, and Morten, of London, for Mr. Nath. J. Holmes, and is erected in the large music-room at the Hall, Primrose Hill Road, built expressly to receive it. The instrument, which stands 50 feet high, 30 feet broad, and 30 feet deep, suffered severe injury from the effects of concussion, in common with the building in which it is erected, at the time of the disastrous explosion of gunpowder on the Regent's Park Canal, near Primrose Hill.

\section{PALAEONTOLOGY AND THE DOCTRINE OF DESCENT}

"THE great biological question of the day is the problem of evolution; but geologists, as Kant says, are the archæologists of nature, and the sole direct and irrefragable evidence of the method whereby living things have become what they are is to be sought among fossil remains" Such were the words spoken by Prof. Huxley on a recent occasion, when receiving from the hands of the president of the Geological Saciety the Wollaston medal ; and the assembled geologists, calling to mind his masterly review of the whole question in his address to them in 1870 , rejoiced to hear their formex president expressing the hope that much of his future labour would be concentrated on this all-important palæontological problem.

The discoveries of such abundant mammalian remains in the Tertiary deposits of the Western territories of America have added much valuable material to that already obtained from the Paris basin, the Sivalik Hills, Pikermi, and many other districts; and we may look forward with confidence to the labours of vertebrate palæontologists for bringing to light many interesting relations between the members of the existing fauna and their ancestral representatives in the later geological periods.

In the meanwhile it may not be uninteresting to point out that among the invertebrata similar evidences of the transitions between life-forms which at first sight appear to ronstitute perfectly distinct groups, are constantly being detected by palæontologists. No opportunity for doing this more effectively could possibly be desired than that which is afforded by the publication of a most suggestive and valuable monograph by the distinguished palæontologist of Vienna, Dr. Neumayr, in conjunction with M. Paul of the Austrian Geological Survey, a work which has just apppeared in the seventh volume of the Abhandlungen der $k$. k. geologischen Reichsanstalt. The title of this memoir is "Die Congerien- und Paludinen-schichten Slavoniens und deren Faunen; ein Beitrag zur Descendenz-Theorie;" and its authors have earned the thanks alike of geologists and biologists, for the important evidence on the great question of evolution which has been the fruit of their patient researches.

The geological formation which has afforded the evidence in question is the grand series of lacustrine beds forming the highest portion of the magnificently developed Tertiaries of Eastern Europe, and which constitute the approximate equivalent, in all probability, of our Pliocene ; and it is a district on the southern limits of the Austrian Empire, the border-land of that area to which the attention of all Europe has been so painfully dra wn for many months past, that has furnished the valuable sections of this formation and the abundant fossil remains, the 